\title{
Food-web structure in the hypertrophic Rietvlei Dam based on stable isotope analysis: Specific and general implications for reservoir biomanipulation
}

\author{
WR Harding ${ }^{1 *}$ and RC Hart ${ }^{2}$ \\ 'DH Environmental Consulting, PO Box 5429, Helderberg 7135, Cape Town, South Africa \\ ${ }^{2}$ School of Life Sciences, University of KwaZulu-Natal, Private Bag X01, Scottsville, Pietermaritzburg, 3209, South Africa
}

\begin{abstract}
Fish predation on zooplankton is the basic foundation for top-down biomanipulation of lacustrine ecosystems. To test this premise, we determined stable isotope (SI) values $\left(\delta^{13} \mathrm{C}\right.$ and $\left.\delta^{15} \mathrm{~N}\right)$ of representative samples of major planktonic (phytoplankton, zooplankton), benthic (submerged macrophytes and associated epiphytes, benthic macro-invertebrates) and nektonic (fish) food-web components, collected from 3 to 7 shallow inshore locations (with additional plankton samples at 1 or 2 deep offshore sites) in Rietvlei Dam over a period of 30 months. The resulting $\delta^{13} \mathrm{C}$ values did not indicate significant consumption of zooplankton by fish, while the $\delta^{15} \mathrm{~N}$ values for fish confirmed their wide trophic separation from zooplankton. Instead, SI values indicated that fish relied mostly on food resources of benthic origin (through direct consumption or piscivory). The SI signatures of individual fish species were consistent with their known feeding habits. The lack of trophic couplings between zooplankton and fish accords with previous gut content analyses of fish and analyses of zooplankton abundance and size structure in hypertrophic reservoirs. Marginal utilisation of zooplankton by indigenous reservoir fish is attributable to their native origin as riverine species unaccustomed to feeding on zooplankton. These findings indicate that top-down biomanipulation is unlikely to be effective as a management tool in eutrophic South African reservoirs. Primary producer components exhibited surprisingly wide and unsystematic temporal fluctuations in both ${ }^{13} \mathrm{C}$ and $\delta^{15} \mathrm{~N}$ values; some potential contributory factors are considered. Changes in phytoplankton $\delta^{13} \mathrm{C}$ values were broadly tracked by zooplankton - their nominal consumers. Some questions arising from the study, and some apparently anomalous findings are identified and discussed.
\end{abstract}

Keywords: $\delta^{13} \mathrm{C}, \delta^{15} \mathrm{~N}$, trophic structure, plankton, benthos, fish, warm-water ecosystems, South Africa

\section{INTRODUCTION}

Nutrient pollution or cultural eutrophication is recognised as posing the major threat to water quality of inland fresh and coastal saline waters globally (Smith and Schindler, 2009). This well-known, serious and intransigent problem is symptomatically manifest in the excessive growth of primary producers released from intrinsic natural nutrient limitation, and generates a cascade of qualitative and quantitative changes in food-web structure and ecosystem functioning (e.g. Carpenter, 2005). In affected lacustrine ecosystems, 'blooms' of 'phytoplankton' (both eukaryote protistan algae and/or prokaryote bacterial cyanophytes) commonly develop. Apart from resulting taste and odour problems and aesthetic considerations, water quality is seriously impaired; treatment costs for potable water increase, while cyanophyte toxins, released during bloom conditions, can seriously compromise human and animal health, sometimes with lethal consequences (Codd et al., 2005; Poste et al., 2011).

Eutrophication is a growing problem in South Africa, and poses a critical threat to the inland water resources of this water-scarce nation, largely reliant on water stored in river impoundments (DWA, 2013). At least 35\% of water stored in such reservoirs is already classed as eutrophic or hypertrophic,

To whom all correspondence should be addressed.

+2721 855-2528; e-mail: info@dhec.co.za

Received 20 November 2012; accepted in revised form 6 August 2013. with an additional $30 \%$ bordering on the eutrophic status (Harding et al., 2009). Since this nutrient pollution is largely attributable to wastewater effluents (Harding, 2008), the problem can be constrained by enforcing appropriate wastewater treatment and effluent discharge restrictions. In practice, such 'preventative' treatment has been largely ineffectual (e.g. DWA, 2009), leading to proposals to implement 'curative' measures notably 'biomanipulation' (Shapiro et al., 1975) - to rehabilitate highly eutrophic systems such as Hartbeespoort Dam (Anon. 2004a, 2004b; Harding et al., 2004).

Biomanipulation is well known as a management tool for eutrophic systems (e.g. Gulati et al., 1990; Moss, 1998; Hansson et al., 1998) which relies on a logical but deceptively simple approach, namely, the restriction of excessive phytoplankton growth by enhancing the 'grazing' pressure exerted by 'herbivorous' zooplankton, particularly large-bodied Daphnia, through removal or reduction of zooplankton predators, especially zooplankton-feeding fish (hereafter termed zooplanktivores). Such 'top-down' biomanipulation through food-web restructuring has featured prominently in global attempts to fight eutrophication, especially in shallow natural lakes, although its success has been variable (e.g. Gulati et al., 1990), and of questionable sustainability (e.g. Benndorf, 1992; Shapiro, 1995; Rask et al., 2002; Gliwicz, 2005; Søndergaard and Jeppesen, 2007; Sierp et al., 2011). Of greater contextual relevance to this study, its suitability in warmer waters is increasingly questioned (Jeppesen et al., 2005, 2007, 2010; Iglesias et al., 2011; Akhurst et al., 2012).

A fishery assessment of Hartbeespoort Dam (Koekemoer and Steyn, 2005) revealed a dominance of 'coarse' fish 
- indigenous catfish (Clarias gariepinus) and canary kurper (Chetia flaviventris), and the exotic carp (Cyprinus carpio), deemed 'undesirable' on account of their stated predation on zooplankton. It was argued that selective removal of these fish would reduce predation on zooplankton, thereby increasing grazing pressure on phytoplankton and thus ameliorating the consequences of eutrophication. In addition thereto, these species impart other negative impacts on aquatic food-webs: high densities of benthic-feeding carp can impart significant bioturbation (bottom-up) impacts in aquatic habitats (e.g. Robertson et al., 1997) and cyprinid removal programmes are becoming increasingly common (e.g. Pinto-Coelho et al., 2005). With respect to food-web disruption, Chetia flaviventris is an extremely efficient carnivore, imparting significant impacts on invertebrates and larval fish (Harding and Koekemoer, 2011). Sharptooth catfish (Clarias gariepinus) exerts a high predatory impact on aquatic food-webs (e.g. Kadye and Booth, 2012).

However, the regional relevance of this intervention measure for eutrophic reservoirs was challenged by Hart (2006) on two fundamental ecological grounds. Firstly, Microcystis, the predominant planktonic autotroph in such waters, is largely inedible to Daphnia (Jarvis et al., 1987), intrinsically constraining potential top-down 'grazer' control of primary production. Secondly, as these reservoirs do not support a guild of zooplanktivores, fish predation on Daphnia and other 'herbivorous' zooplankton is limited, negating the need for fish removal. In the absence of specialist 'pelagic' zooplanktivores, Hart (2006) postulated that zooplankton predation by fish would be confined to opportunistic feeding by juvenile fish, restricting its occurrence both spatially, to near-shore littoral regions occupied by juvenile fish sheltering from their own predators (e.g. Werner et al., 1983; Schlosser, 1987), and also temporally to the fish breeding season.

The present study was planned to test the challenges raised by Hart (2006), using Hartbeespoort Dam as an empirical case study prior to implementing fish removal there (or in other neighbouring eutrophic reservoirs also dominated by 'coarse' fish (Harding and Koekemoer, 2011)). However, preemptive fish removal commenced as a remedial intervention in Hartbeespoort in 2007 and has continued since (Venter et al., 2012). As permission was not granted to conduct the present study on Hartbeespoort Dam, the project was relocated to the hypertrophic Rietvlei Dam.

We stress that the study was confined to examining prospects for 'top-down' biomanipulation. It rests on the null hypothesis, stemming from Hart (2006), that fish-zooplankton couplings are absent or weak in eutrophic South African reservoir ecosystems.

We used stable isotope analysis (SIA) to assess the extent to which zooplankton featured in the diet of any major fish species in Rietvlei. SIA is a well-known and widely accepted technique that uses stable isotopes (SI) of carbon and nitrogen to examine feeding links and associated food-web structure and dynamics (Peterson and Fry, 1987; Post, 2002; Thompson et al., 2005; Grey, 2006; Fry, 2006; Karasov and Martínez del Rio, 2007). Fundamentally, the ratio of ${ }^{13} \mathrm{C}$ to ${ }^{12} \mathrm{C}$ isotopes - denoted as $\delta^{13} \mathrm{C}$ (in units of \%o), provides a distinctive signature that reflects the origin (primary producer source) of a particular food, and allows it to be identified and tracked as it travels through successive consumers (DeNiro and Epstein, 1978). The corresponding ratio of ${ }^{15} \mathrm{~N}$ to ${ }^{14} \mathrm{~N}\left(\delta^{15} \mathrm{~N}\right)$ provides a parallel indication of the number of 'steps' through which a particular food (identified by its $\delta^{13} \mathrm{C}$ value) has been transferred in the food-web, i.e., the trophic level of the consumer involved (DeNiro and Epstein,
1981; Fry and Sherr, 1984).

Metabolic differentiation of heavier and lighter isotope fractions in catabolic and anabolic pathways results in successive step-wise isotopic shifts (trophic fractionation values) between a particular food and its subsequent consumer(s). As trophic fractionation is influenced by a variety of factors (Adams and Sterner, 2000; McClelland and Montoya, 2002; McCutchan et al., 2003; Vanderklift and Ponsard, 2003), values vary both within and between ecosystems, and fractionation values (of $\mathrm{N}$ in particular) should ideally be determined for individual consumers on a case-by-case basis (Mill et al., 2007). However, as this is beyond the scope of most studies, general values are commonly applied. Here, we relied on the average trophic-step enrichment values of $+0.4 \%$ for $\delta^{13} \mathrm{C}$ and $+2.3 \%$ o for $\delta^{15} \mathrm{~N}$ reported for aquatic consumers by McCutchan et al. (2003) (cf. corresponding values of +0.4 and $+3.4 \%$ reported by Post (2002) and $\leq+1 \% 0$ and $+3.0 \%$ justified for general use by Grey (2006)).

SIA is increasingly used globally in freshwater research (Grey, 2006) and has been applied in South African estuarine ecosystem food-web studies (e.g. Froneman, 2002; Kibirige et al., 2002; Richoux and Froneman, 2007). To our knowledge, its use in South African freshwater ecosystems has been limited to dietary analysis of single species (Kadye and Booth, 2012), and this is the first integrated SI study of an integrated food-web of a lacustrine ecosystem in the country.

\section{STUDY SITE}

Rietvlei Dam (255' $34.8^{\prime \prime}$ S, $\left.28^{\circ} 16^{\prime} 47.6^{\prime \prime} \mathrm{E}\right)$ is a warm, monomictic reservoir on the Hennops River, near Irene, south of Pretoria, South Africa. At full supply level, it has a surface area of $2.06 \mathrm{~km}^{2}$, mean and maximum depths of $6.2 \mathrm{~m}$ and $19 \mathrm{~m}$, and a total storage capacity of $12.3 \times 10^{6} \mathrm{~m}^{3}$ (Harding and Koekemoer, 2011). Its median total phosphorus (TP) concentration of $0.25 \mathrm{mg} \cdot \ell^{-1}$ between 1990 and 2005 (Harding, 2008) clearly renders it hypertrophic $\left(\mathrm{TP}>0.15 \mathrm{mg} \cdot \ell^{-1}\right)$, although its corresponding median chlorophyll level $\left(24.3 \mu \mathrm{g} \cdot \ell^{-1}\right)$ is enigmatically low, plausibly on account of its nitrogen-limited status (Ashton 1981). During this study (July 2009 to December 2011), the reservoir was thermally stratified at approximately $6 \mathrm{~m}$ depth between September and February, and fully mixed between March and August. During thermal stratification, dissolved oxygen saturation levels at depths below $\sim 8 \mathrm{~m}$ were commonly $<20 \%$ (Harding et al., 2012).

\section{MATERIALS AND METHODS}

The locations of sites used for regular sample collections during the study are shown in Fig. 1, while Table 1 provides a breakdown of resulting SI determinations made for the various foodweb components examined.

\section{Sample collection, preparation and processing}

The protocol followed by this study was in accordance with that of Jeppesen et al., (2002), as well as guidelines provided to the researchers (Jeppesen, 2008).

Plankton was collected qualitatively using repeated vertical hauls with Wisconsin-type plankton nets. Phytoplankton was collected in hauls from a maximum depth of $7 \mathrm{~m}$ to the surface with a net of $20 \mu \mathrm{m}$ mesh aperture, and zooplankton in hauls from just above the lake bed to the surface using an $80 \mu \mathrm{m}$ mesh net. The resulting concentrated plankton-bucket samples 


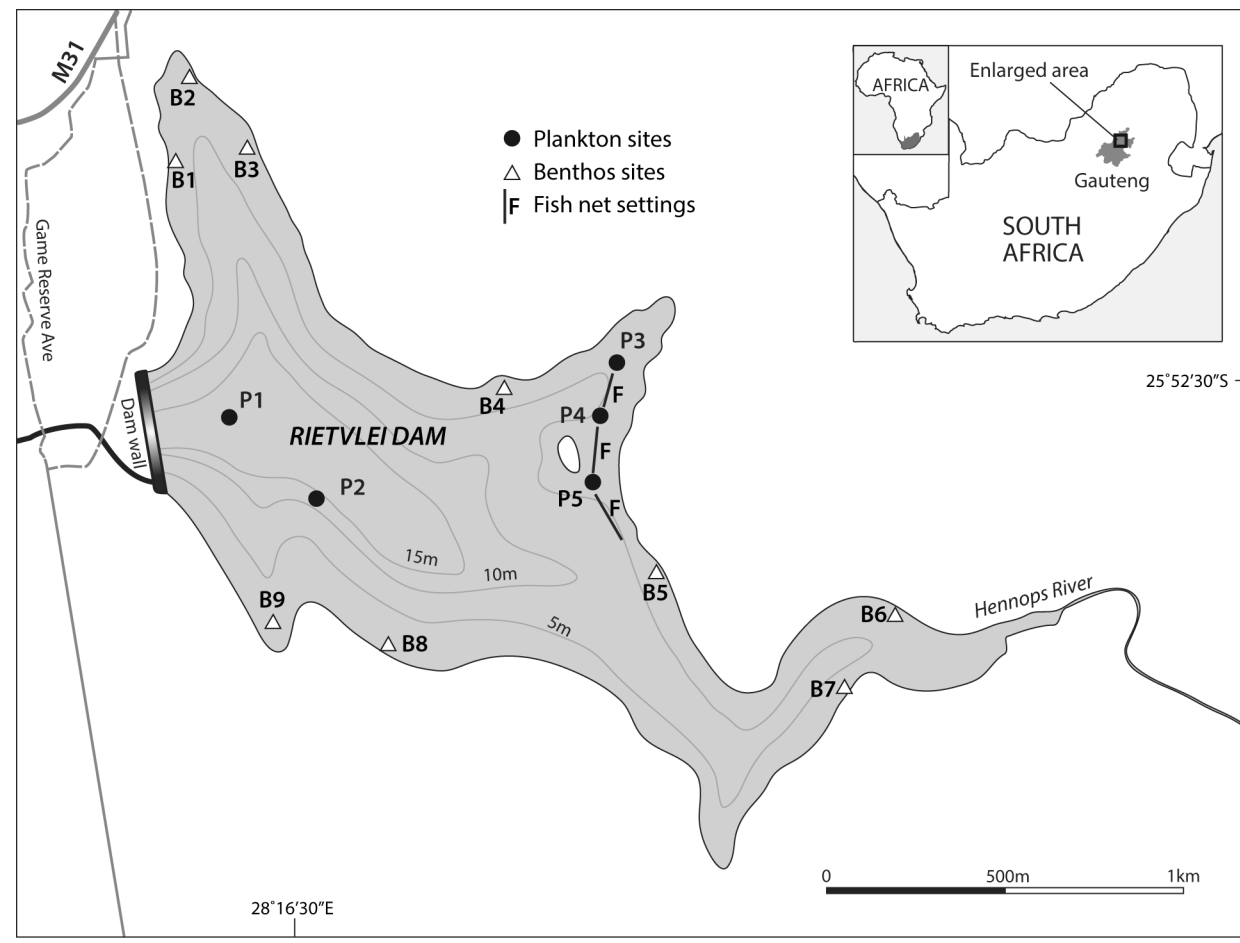

Figure 1

Outline of Rietvlei Dam, indicating bathymetry and collecting sites for plankton $(P)$, benthos $(B)$ and fish (F) samples

TABLE 1

Synopsis of spatio-temporal sampling coverage of specified food-web components (upper) and ancillary details for samples of specified fish species (lower). 'Coarse' taxa are marked *; superscripts identify sample source, viz., 'gillnetting and ${ }^{2}$ angler catches (additional or exclusive).

\begin{tabular}{|c|c|c|c|c|}
\hline \multirow{3}{*}{ Food-web component } & \multicolumn{3}{|c|}{ Sampling coverage } & \multirow{3}{*}{$\begin{array}{l}\text { Number } \\
\text { of SIA } \\
\text { samples } \\
(n)\end{array}$} \\
\hline & \multicolumn{2}{|c|}{ Sites } & \multirow{2}{*}{\begin{tabular}{|c|} 
Dates \\
(Months)
\end{tabular}} & \\
\hline & In-shore & $\begin{array}{c}\text { Off- } \\
\text { shore }\end{array}$ & & \\
\hline Phytoplankton & 3 & $1-2$ & 19 & 84 \\
\hline Zooplankton & 3 & $1-2$ & 19 & 234 \\
\hline Small $(\leq 200 \mu \mathrm{m})$ & & & & 66 \\
\hline Medium $(200-500 \mu \mathrm{m})$ & & & & 85 \\
\hline Large $(>500 \mu \mathrm{m})$ & & & & 82 \\
\hline Macrophytes & $3-9$ & 0 & 17 & 107 \\
\hline Epiphytes & $3-9$ & 0 & 11 & 66 \\
\hline Macrobenthos & 9 & 0 & 1 & 10 \\
\hline Fish & 4 & 0 & 1 & 42 \\
\hline 'Coarse' species (`below) & & & & 21 \\
\hline 'Other' species. & & & & 21 \\
\hline \multicolumn{5}{|l|}{ Fish sample details } \\
\hline \multirow[b]{2}{*}{ Taxon } & \multicolumn{3}{|c|}{ Size range } & \\
\hline & $\begin{array}{l}\text { Length } \\
(\mathrm{cm})\end{array}$ & & $\begin{array}{l}\begin{array}{l}\text { Fresh } \\
\text { veight }\end{array} \\
\end{array}$ & \\
\hline${ }^{\star}{ }^{*}$ Clarias gariepinus ${ }^{1,2}$ & $52-72$ & & $-3.3 \mathrm{~kg}$ & 9 \\
\hline${ }^{\star}$ Cyprinus carpio $^{2}$ & & & $-18 \mathrm{~kg}$ & 6 \\
\hline${ }^{{ }^{*} \text { Chetia flaviventris }{ }^{1,2}}$ & $10.5-20$ & & $-100 \mathrm{~g}$ & 6 \\
\hline Pseudocrenilabrus philander ${ }^{1}$ & $6.5-9$ & & $-11 \mathrm{~g}$ & 5 \\
\hline Labeobarbus polylepis ${ }^{1,2}$ & $46-50$ & 2.0 & $-2.5 \mathrm{~kg}$ & 5 \\
\hline Tilapia sparrmanii ${ }^{1}$ & $10-15.5$ & & $1-75 \mathrm{~g}$ & 5 \\
\hline Barbus paludinosus ${ }^{1}$ & $6.5-7.5$ & & $4-6 g$ & 5 \\
\hline Micropterus salmoides ${ }^{2}$ & & & & 1 \\
\hline
\end{tabular}

were diluted with $20 \mu \mathrm{m}$-filtered lake water to roughly $500 \mathrm{m \ell}$ and stored in sealed $1 \ell$ containers in a cold-box for return to the field laboratory within $\sim 2 \mathrm{~h}$. In the field laboratory, phytoplankton samples were sieved through a $35 \mu \mathrm{m}$ screen to remove zooplankton before oven-drying at $\pm 60^{\circ} \mathrm{C}$. Lake water filtered through $20 \mu \mathrm{m}$ mesh was used to rinse zooplankton samples thoroughly, and to make up several live subsamples $(\sim 1 \ell)$ which were stored overnight at $\pm 4^{\circ} \mathrm{C}$ to allow gutclearance since gut mass inclusion may introduce substantial errors of $>3 \%$ in copepod $\delta \mathrm{C}$ and $\delta \mathrm{N}$ values (Feuchtmayr and Grey, 2003). These subsamples were subsequently pooled, and differentially filtered through 200 and $50 \mu \mathrm{m}$ mesh sieves to provide 3 zooplankton size fractions, hereafter termed 'large' $(>200 \mu \mathrm{m})$, 'medium' $(\geq 50 \leq 200 \mu \mathrm{m})$ and 'small' $(<50 \mu \mathrm{m})$, for vacuum-concentration and oven-drying at $\pm 60^{\circ} \mathrm{C}$. All samples of plankton (and other food-web components - see below) were stored dry until SIA.

Two dominant macrophyte groups were recorded during this study, these being marginal stands of the emergent reed Phragmites australis and the submerged pondweed, Potamogeton, the latter comprising 3 species (P. pectinatus, P. schweinfurtii and P. crispus). This macrophyte assemblage remains unchanged from that recorded previously (e.g. Ashton, 1980), although the shoreline fringe of $P$. australis has become increasingly dominant in response to stabilised water levels (Harding, personal observation). Macrophyte samples comprised pooled collections of leaves of various Potamogeton species cut from the plant canopy at roughly $30 \mathrm{~cm}$ below the surface. Samples were washed clean of sand and silt, and kept cool and fresh prior to air-drying at $\sim 60^{\circ} \mathrm{C}$. Epiphyte samples (largely diatoms) were collected off the macrophyte leaves, using the 'shake in bag' method (Taylor et al., 2007). The resulting suspensions were concentrated by settling before drying and storage for SIA. Benthic macro-invertebrates (zoobenthos) were collected adjacent to macrophyte sampling sites using a standard Birge-Ekman sediment grab sampler. Samples were 
sieved through $1 \mathrm{~mm}$ mesh screens to separate zoobenthos from sediment, before removing the former for drying and storage. Zoobenthos sampling was initiated only when unfolding SI results supporting our null hypothesis regarding fishzooplankton couplings invoked the need to consider alternative food sources.

Fish were collected in gill-nets set overnight in October 2009, using the procedures described in Harding and Koekemoer (2011). The logistical constraints for this study precluded the use of other fishing gear. Samples of dorsal muscle were removed from specimens of measured fork or total length (FL or TL) and fresh weight, wrapped in tin foil and frozen until oven-dried at $60^{\circ} \mathrm{C}$ and then stored in a desiccator pending SIA. Additional samples of 'coarse' species of unrecorded size were collected from anglers when the opportunity arose.

\section{Stable isotope analysis}

Values of $\delta^{13} \mathrm{C}$ and $\delta^{15} \mathrm{~N}$ of dried samples were determined by the Stable Light Isotope Unit laboratory at the University of Cape Town. Samples weighed to $\pm 1 \mu \mathrm{g}$ with a Sartorius microbalance were encapsulated in tin cups, and combusted in a Flash EA 1112 series elemental analyser (Thermo Finnigan, Milan, Italy) coupled to a Delta Plus XP Isotope Ratio Mass Spectrometer (Thermo electron, Bremen, Germany) through a Conflo III gas control unit (Thermo Finnigan, Bremen, Germany). Routine calibration samples were run in parallel, using a range of in-house standards (as listed below), all calibrated in turn against IAEA (International Atomic Energy Agency) standards.

The standards used were:

- Choc - a commercial chocolate/egg mixture

- Sucrose - 'Australian National University (ANU)' sucrose

- Valine - DL Valine purchased from Sigma

- MG - Merck Gel - a proteinaceous gel produced by Merck

- Seal - a seal bone, demineralised and dissolved in acid, and then reconstituted in gel form

- Lentil - dried lentils

- Nastd - Dried nasturtium leaves

- $\mathrm{NH}_{4} \mathrm{Cl}$ - as purchased from a chemical supplier

Isotope values were calculated using the standard equation

$$
\delta X=\left[\left(R_{\text {sample }}-R_{\text {standard }}\right) / R_{\text {sample }}\right] \times 1000
$$

where:

$R$ is the ratio of heavy to light isotopes of the element $(X)$ in samples $\left(R_{\text {sample }}\right)$ and standards $\left(R_{\text {standard }}\right)$.

Nitrogen is expressed in terms of its value relative to atmospheric nitrogen, while carbon is expressed in terms of its value relative to Pee-Dee Belemnite. The precision of repeated measurements was approximately $0.1 \%$ for both $\delta^{13} \mathrm{C}$ and $\delta^{15} \mathrm{~N}$.

Although lipid content is well known to affect $\delta^{13} \mathrm{C}$ values, there is neither consensus on the need to correct for its influence (Post et al., 2007), nor any standard correction protocol (Logan et al., 2008). As chemical lipid-extraction prior to $\delta^{13} \mathrm{C}$ determination can alter parallel determinations of $\delta^{15} \mathrm{~N}$ on the same sample (Post et al., 2007) - although this is neither inevitable (Ingram et al., 2007) nor consistent (Logan et al., 2008) - a posteriori mathematical normalisation of $\delta^{13} \mathrm{C}$ values using the lipid-correction equations is often used. Recommendations in this regard also remain contradictory (Kiljunen et al., 2006; Post et al., 2007; Smyntek et al., 2007), underscoring uncertainties that persist in ecological use of SI (Gannes et al., 1997; Karasov and Martínez del Rio, 2007). Following Post et al. (2007), we corrected for both autotroph and consumer values rather than zooplankton alone (Smyntek et al., 2007). The corrections $\left(\Delta \delta^{13} \mathrm{C}\right)$ rely on $\%$ carbon values $(\% \mathrm{C})$ and carbon to nitrogen ratios $(\mathrm{C}: \mathrm{N})$ determined routinely during SIA:

- For autotrophs (phytoplankton, macrophytes and epiphytes)

$\Delta \delta^{13} \mathrm{C}=-3.02+0.09 \times \% \mathrm{C}$ (where $\left.\% \mathrm{C} \geq 40 \%\right)$

$\Delta \delta^{13} \mathrm{C}=-5.83+0.14 \times \mathrm{x}$ C (where $\left.\% \mathrm{C}<40 \%\right)$

- For consumers (zooplankton, zoobenthos and fish)

$\Delta \delta^{13} \mathrm{C}=-3.32+0.99 \times \mathrm{C}: \mathrm{N}$.

Logistical constraints for this pilot study did not allow for carbonate removal prior to analysis. However, as per Søreide et al. (2006), this step was deemed unnecessary.

\section{Statistical analysis and data interpretation}

All basic data analysis was undertaken with Microsoft Excel 2010. Statistical tests were undertaken using Statistica 7 and the Data Analysis Package in Excel. Conventional parametric correlation analysis was used to determine Pearson's $r$. Analysis of variance was used to test between-site differences in average SI values (one-way ANOVA) and to compare within-site and between-time variability (two-way ANOVA). Differences were considered statistically significant at $p<0.05$.

Potential food linkages between zooplankton and fish taxa were examined using overall average $\delta^{13} \mathrm{C}$ and $\delta^{15} \mathrm{~N}$ values of zooplankton (large and medium size classes - see 'Results' section) and individual fish species. A consolidated food-web for the Rietvlei system was assembled using average values of other food components listed in Table 1. Separation of $\geq 0.4 \%$ o in $95 \%$ limits of $\delta^{13} \mathrm{C}$ was interpreted as a firm contra-indication of dietary coupling between respective food-web components, while a corresponding difference of $\geq 2.4 \%$ in average $\delta^{15} \mathrm{~N}$ values was interpreted as one trophic level separation (McCutchan et al., 2003).

\section{RESULTS}

Stable isotope variation in primary producer food sources and zooplankton consumers

Temporal changes in $\delta^{13} \mathrm{C}$ and $\delta^{15} \mathrm{~N}$ values of phytoplankton $(\mathrm{P})$, macrophytes $(\mathrm{M})$ and epiphytes $(\mathrm{E})$ through the study are shown in Fig. 2. Unexpectedly wide fluctuations were evident in both isotopes (e.g. $12.5 \%$ and $17.5 \%$ o for phytoplankton $\delta^{13} \mathrm{C}$ and $\delta^{15} \mathrm{~N}$ ). Temporal covariance between $\delta^{13} \mathrm{C}$ values of these autotrophic components was also surprisingly weak, with Pearson correlation coefficients (and $p$ values) of 0.210 (0.418), $0.315(0.345)$ and $0.620(0.042)$ for P vs. M, P vs. E and M vs. E, respectively. Comparable statistics for $\delta^{15} \mathrm{~N}$ were 0.030 (0.908), $0.123(0.719)$ and $0.571(0.066)$. Isotope values of epiphytes and macrophytes were expected to correspond closely on account of their intimate physical association, but correlations were just significant $(p=0.042)$ for $\delta^{13} \mathrm{C}$ and weak $(p=0.066)$ for $\delta^{15} \mathrm{~N}$.

The regularity and consistency of phytoplankton sampling at inshore and offshore sites permitted an examination of spatial variation in stable isotope values of this autotrophic component. One-way ANOVA of samples at Sites P1 to P4 on 15 dates showed no significant between-site differences in either $\delta^{13} \mathrm{C}$ $\left(F_{3,56}=0.130, p=0.942\right)$ or $\delta^{15} \mathrm{~N}\left(F_{3,56}=0.076, p=0.973\right)$ values, justifying subsequent combination of results from all sites. 

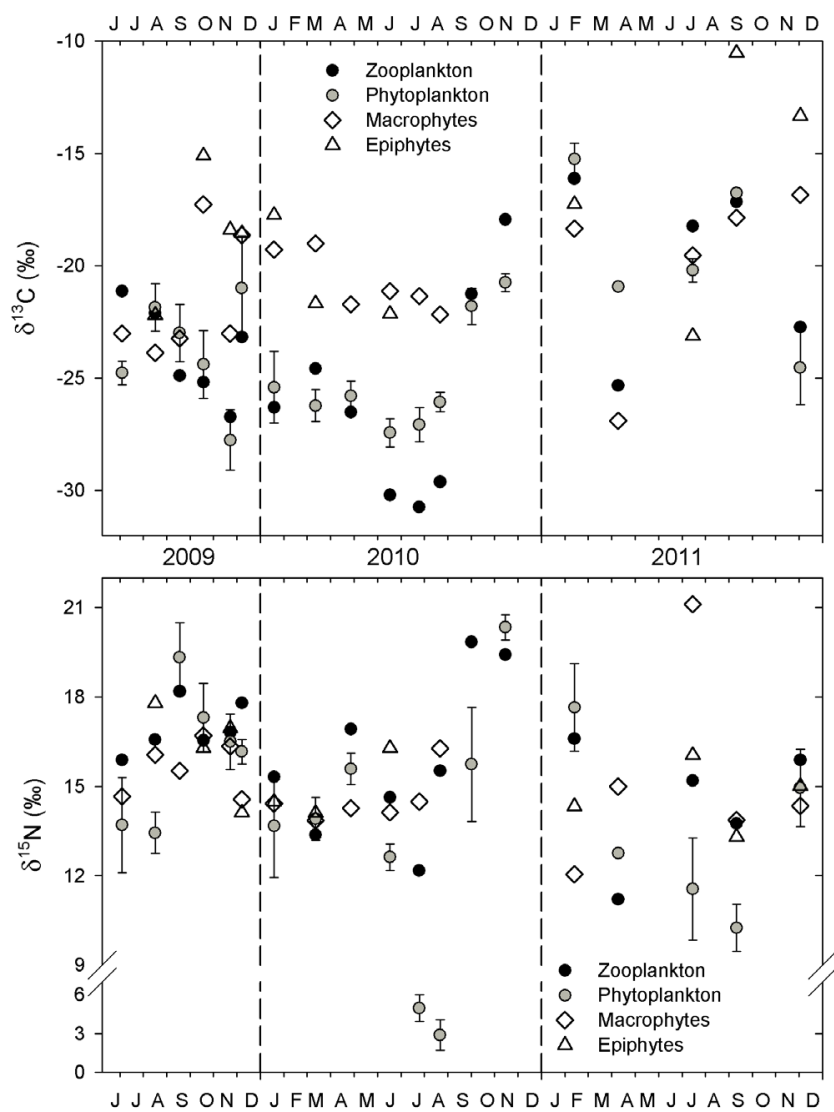

Figure 2

Temporal variation in $\delta^{13} \mathrm{C}$ (upper) and $\delta^{15} \mathrm{~N}$ (lower) signatures obtained for primary producer components, and aggregate zooplankton. Error bars $( \pm 1 S D)$ are only shown for phytoplankton, where sample number ( $n$ $=4$ to 5) was consistent on each date.
Two-way ANOVA for the same data demonstrated a highly significant temporal effect on both $\delta^{13} \mathrm{C}\left(F_{3,14}=58.893\right.$, $p<0.001)$ and $\delta^{15} \mathrm{~N}\left(F_{3,14}=71.398, p<0.001\right)$, with insignificant between-site differences $\left(p=0.127\right.$ for $\delta^{13} \mathrm{C}$ and $p=0.254$ for $\left.\delta^{15} \mathrm{~N}\right)$.

In keeping with anticipated direct trophic linkages, temporal covariance in $\delta^{13} \mathrm{C}$ was strong between zooplankton and phytoplankton (Fig. 2), in contrast to the weak covariance between $\delta^{13} \mathrm{C}$ values of the autotroph components. Correlations of phytoplankton with large, medium and small zooplankton were all highly significant $(p \leq 0.0001)$, with respective $r$ values of $0.850,0.847$ and 0.786 . Most corresponding values for $\delta^{15} \mathrm{~N}$ were lower $(0.500,0.668$ and 0.808$)$ but were all significant ( $p$ between 0.029 and $\leq 0.001$ ). Correlations of phytoplankton with combined large and medium zooplankton values (see below) were very strong both for $\delta^{13} \mathrm{C}(r=0.853, p \leq 0.0001)$ and $\delta^{15} \mathrm{~N}(r=0.627, p=0.004)$.

\section{Feeding links between zooplankton and fish}

Figure 3 provides a consolidated biplot of overall average $\delta^{13} \mathrm{C}$ and $\delta^{15} \mathrm{~N}$ values of the food-web components examined in this study. Before considering zooplankton as a dietary component for fish, we examine some aspects of the zooplankton SI values themselves.

Average $\delta^{13} \mathrm{C}$ signatures of large and medium zooplankton size fractions were statistically indistinguishable, but greatly enriched by around 3\%o (Fig. 3) in small zooplankton. The average $\delta^{15} \mathrm{~N}$ value of small zooplankton was also disparately depleted, lying roughly one trophic level below medium and large zooplankton separately $(-2.45 \%,-3.39 \%)$, or on aggregate $(-2.9 \%)$. More surprisingly, small zooplankton were both $\delta^{15} \mathrm{~N}$ depleted $(-0.79 \%)$ and $\delta^{13} \mathrm{C}$ enriched $(+2.76 \%$ ) relative to phytoplankton. Regular microscopic inspections of small 'zooplankton' samples $(<50 \mu \mathrm{m})$ revealed an invariable (and

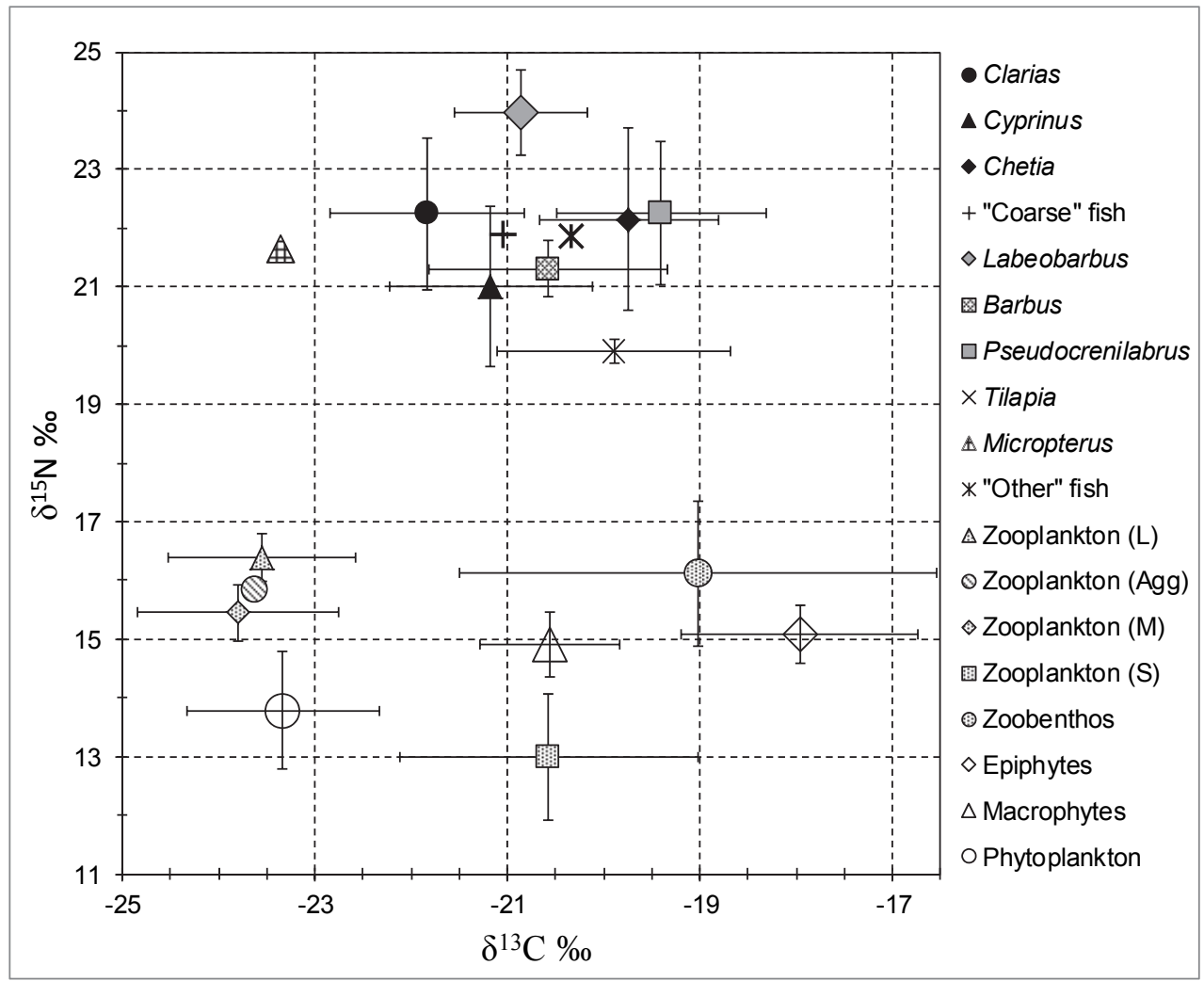

Figure 3

A biplot of overall average $\delta^{13} \mathrm{C}$ and $\delta^{15} \mathrm{~N}$ values of fish species and other designated food-web components. Error bars reflect \pm 1 SE for zoobenthos, and $95 \%$ confidence ranges for all other specified components. Where possible, symbol shading reflects functional composition. Primary producers (unfilled); invertebrate consumers (light stippling); 'coarse' fish (solid shading); 'other' fish (dark stippling). Error bars for averages of aggregate zooplankton, 'coarse' and 'other' fish are omitted for clarity. The single value for Micropterus is shown simply for inclusivity. 
Table 2

Absolute differences between average stable isotope values of fish (listed 'groups' and species) and aggregated zooplankton, with corresponding separations in $95 \%$ confidence limits (excluding Micropterus). The single value within (i.e. less than) the critical limits for distinctiveness ( $0.4 \%$ of $\delta^{13} \mathrm{C}$ and $2.3 \%$ ofor $\left.\delta^{15} \mathrm{~N}\right)$ is emboldened.

\begin{tabular}{|l|c|c|c|c|}
\hline \multirow{2}{*}{ Fish group or species } & \multicolumn{2}{|c|}{$\begin{array}{c}\text { Difference between } \\
\text { mean values }\end{array}$} & \multicolumn{2}{c|}{$\begin{array}{c}\text { Separation of 95\% } \\
\text { confidence limits }\end{array}$} \\
\cline { 2 - 5 } & $\boldsymbol{\delta}^{\mathbf{1 3}} \mathbf{C}$ & $\boldsymbol{\delta}^{15} \mathbf{N}$ & $\boldsymbol{\delta}^{13} \mathbf{C}$ & $\boldsymbol{\delta}^{15} \mathbf{N}$ \\
\hline All fish combined & +2.95 & +5.98 & 1.83 & 5.17 \\
\hline 'Coarse' species & +2.60 & +5.99 & 1.26 & 4.96 \\
\hline 'Other' species & +3.30 & +5.97 & 2.06 & 4.93 \\
\hline Clarias gariepinus & +1.81 & +6.36 & $\mathbf{0 . 0 9}$ & 4.75 \\
\hline Cyprinus carpio & +2.47 & +5.13 & 0.71 & 3.44 \\
\hline Chetia flaviventris & +3.90 & +6.27 & 2.26 & 4.40 \\
\hline Pseudocrenilabrus philander & +4.24 & +6.38 & 2.43 & 4.83 \\
\hline Barbus paludinosus & +3.06 & +5.43 & 1.30 & 4.49 \\
\hline Labeobarbus polylepis & +2.78 & +8.10 & 1.39 & 7.04 \\
\hline Tilapia sparrmanii & +3.75 & +4.02 & 1.82 & 3.50 \\
\hline Micropterus salmoides & +0.27 & +5.78 & - & - \\
\hline
\end{tabular}

physically unavoidable) inclusion of large autotrophic genera such as Ceratium, Aulacoseira, Pediastrum and Microcystis, which often comprised a large and sometimes volumetrically predominant fraction of this notional 'zooplankton' sample. This phytoplankton 'contamination' may partly explain the $\delta^{13} \mathrm{C}$ enrichment noted above. Lipid correction (see 'Methods' section) using the 'consumer' equation adjusted 'raw' $\delta^{13} \mathrm{C}$ values by $+3.98 \%$ on average, whereas use of 'autotroph' equations resulted in a change of only $+0.88 \%$; based on the latter, lipid-corrected $\delta^{13} \mathrm{C}$ values of all fractions are statistically comparable. Owing to this variable 'contamination' by autotrophs, subsequent consideration of zooplankton in the food-web is based exclusively on large and medium size fractions - individually or on aggregate.

Excluding the single specimen of Micropterus, Fig. 3 shows clear differences between average $\delta^{13} \mathrm{C}$ signatures of zooplankton and all fish species, with clear statistical separation for all taxa apart from Clarias, which overlapped minimally with large and medium zooplankton). On average, fish were clearly $\delta^{13} \mathrm{C}$ enriched (right-shifted) by between +2 and $+4 \%$ relative to aggregate zooplankton (Table 2 ). These results clearly exclude zooplankton as a direct food source for any fish species apart from Clarias, for which $95 \%$ separation $(0.09 \%$ ) did not meet the prescribed $0.4 \%$ minimum, despite an average difference of $1.8 \%$.

Average $\delta^{15} \mathrm{~N}$ values of fish were between +4 and $+8 \%$ o higher than zooplankton (Table 2), indicating their dietary placement between nearly 2 and 3-plus nominal trophic steps above zooplankton. Although Tilapia was closest to zooplankton in terms of $\delta^{15} \mathrm{~N}\left(+4 \%\right.$ ), its $3.75 \%$ higher $\delta^{13} \mathrm{C}$ value clearly negates its utilisation of zooplankton. Of greater relevance to this study, $\delta^{15} \mathrm{~N}$ enrichment in Clarias $(+6.4 \%$ ) indicates its position nearly 3 trophic steps above zooplankton. Thus, despite its statistical proximity to zooplankton in terms of $\delta^{13} \mathrm{C}$ (see above), zooplankton is negated as a direct food source. Collectively, the $\delta^{15} \mathrm{~N}$ signatures affirm the general trophic separation of fish and zooplankton evident in the corresponding $\delta^{13} \mathrm{C}$ signatures.

It should be noted that, although average zooplankton $\delta^{15} \mathrm{~N}$ values were $+1.25,+1.13$ and $+0.96 \%$ higher up until October 2009 than thereafter, for large, medium and aggregate fractions, respectively, $(t$ and $(p)$ values of $2.54(0.01), 2.08(0.04)$ and $2.51(0.01)$, respectively), the corresponding $\delta^{13} \mathrm{C}$ values were indistinguishable (respective $t$ (and $p$ ) values of $0.23(0.82)$, $1.07(0.29)$ and $1.11(0.23)$ ). Accordingly, neither the temporal inconsistency in sampling coverage of fish and zooplankton components (Table 1), nor the wide temporal variation observed in planktonic components, compromise the overall conclusion that zooplankton are insignificant in fish diets.

In the context of this study, the SI values of 'coarse' fish (Clarias, Cyprinus and Chetia) are of particular relevance. Zooplankton is clearly negated as a direct food source for these fish (Table 2), both on the basis of food type (2.6\% difference in $\delta^{13} \mathrm{C}$ ), and trophic level (6.0\%o difference in $\left.\delta^{15} \mathrm{~N}\right)$. And, as noted above, despite the proximity of $95 \%$ limits for $\delta^{13} \mathrm{C}$ in Clarias, its average $\delta^{15} \mathrm{~N}$ enrichment of $+6.4 \%$ strongly contraindicates direct feeding on zooplankton. Morphologically, Chetia seems the most likely visual zooplanktivore among the coarse fishes. However, it showed very wide separation from zooplankton, both in $\delta^{13} \mathrm{C}(+3.9 \%)$ and $\delta^{15} \mathrm{~N}(+6.3 \% 0)$, strongly counterindicating its prospective zooplanktivory. The overall evidence indicates that zooplanktivory by coarse fish is negligible, and totally excludes obligate or exclusive zooplanktivory.

\section{Wider perspectives on overall food-web structure and fish diets}

Given that zooplankton is essentially excluded as a significant dietary component of both 'coarse' and other fish (see preceding section), the alignment of most fish $\delta^{13} \mathrm{C}$ values with macrophytes (Fig. 3) is consistent with their reliance on a 'benthic' primary food resource - the only alternative aquatic source for non-piscivorous fish. The generality of this fish-benthic coupling is more obvious (and statistically stronger) for aggregated fish data (Table 3) than taxon-specific values (Fig. 3).

Although $\delta^{13} \mathrm{C}$ values of Cyprinus and Clarias lie between those of planktonic and benthic primary producers (macrophytes) (Fig. 3), evidence that they use planktonic resources by eating zooplankton is weak. The restricted data for zoobenthos suggests their role as a trophic intermediary, although their $\delta^{15} \mathrm{~N}$ values are lower than expected in this regard. Broad overlap of zoobenthos and epiphyte $\delta^{13} \mathrm{C}$ values, in contrast to the limited overlap between fish and epiphytes, accords with general differences in 'habitat' and feeding abilities of zoobenthos 


\begin{tabular}{|c|c|c|}
\hline \multicolumn{3}{|c|}{$\begin{array}{c}\text { Table } 3 \\
\text { Lower and upper } 95 \% \text { confidence limits of stable isotope values of } \\
\text { the specified components (disregarding negative } \delta^{13} \mathrm{C} \text { notation for } \\
\text { clarity). Values of } \delta^{13} \mathrm{C} \text { are aligned to emphasize the distinction between } \\
\text { traditionally planktonic and benthic sources (despite } 3 \text {-fold domination of } \\
\text { the former by near-shore samples). }\end{array}$} \\
\hline Food-web component & \begin{tabular}{|l|}
${ }^{13} \mathrm{C}-95 \%$ range \\
(without negative notation)
\end{tabular} & $\delta^{15} \mathrm{~N}-95 \%$ range \\
\hline Source habitat & Planktonic $\rightarrow$ & Combined \\
\hline Fish - all taxa & $21.10-20.28$ & $21.38-22.34$ \\
\hline Fish - 'other' spp. & $20.87-19.80$ & $21.13-22.57$ \\
\hline Fish - 'coarse' spp. & $21.67-20.41$ & $21.16-22.57$ \\
\hline Benthic invertebrates & $24.61-13.43$ & $13.59-18.65$ \\
\hline Epiphytes & $19.19-16.73$ & $14.60-15.58$ \\
\hline Macrophytes & $21.28-19.84$ & $14.35-15.45$ \\
\hline Zooplankton - Aggregate & $24.35-22.93$ & $15.56-16.20$ \\
\hline Zooplankton - Large & $24.52-22.57$ & $15.98-16.79$ \\
\hline Zooplankton-Medium & $24.84-22.75$ & $14.96-15.93$ \\
\hline Phytoplankton & $24.13-22.53$ & $12.79-14.78$ \\
\hline
\end{tabular}

and fish.

In keeping with their nominal role as phytoplankton feeders, overall average $\delta^{15} \mathrm{~N}$ values of large and medium zooplankton were significantly enriched relative to phytoplankton (Table 3 ), by $+2.6 \%$ and $+1.7 \%$, respectively, (one or nearly one trophic level above phytoplankton). On average, $\delta^{15} \mathrm{~N}$ values were surprisingly lower (by $-0.8 \%$ ) in small zooplankton than phytoplankton. Although statistically insignificant, this difference is nevertheless anomalous (unless the large phytoplankton 'contaminants' in this fraction themselves have lower $\delta^{15} \mathrm{~N}$ values than the collective phytoplankton assemblage).

Excluding Micropterus, fish $\delta^{13} \mathrm{C}$ values indicate dietary overlap across all species, apart from separation between Clarias and both Chetia and Pseudocrenilabrus (Fig. 3). Nevertheless, the $\delta^{13} \mathrm{C}$ and $\delta^{15} \mathrm{~N}$ profiles are encouragingly coherent with their respective foods and feeding biology as summarised by Skelton (1993). For example, the overlap in $\delta^{13} \mathrm{C}$ values of Tilapia, macrophytes and epiphytes is consistent with an omnivorous fish feeding on plants and their associated fauna; intermediate alignment of Cyprinus $\delta^{13} \mathrm{C}$ values between phytoplankton and macrophytes accords with its bottomgrubbing feeding mode and consumption of sedimented algal and detrital particles. Lower $\delta^{15} \mathrm{~N}$ values of Tilapia and bottomgrubbing Cyprinus accord with a lower trophic position commensurate with their reportedly prevalent omnivory, while higher $\delta^{15} \mathrm{~N}$ values in Labeobarbus, Pseudocrenilabrus, Clarias and Chetia accord with their general or seasonal predatory feeding habits. The somewhat intermediate position apparent in Barbus is consistent with its diverse dietary range of mostly animal foods.

\section{DISCUSSION}

\section{Reality of and basis for a predominantly benthic food-web}

The present SI findings reflect a reliance of fish on food resources of benthic rather than planktonic origin. Is this a realistic reflection of trophic structure in Rietvlei, or merely an artefact of spatial bias in our fish samples (all collected from shallow inshore/littoral regions)? Importantly, the overriding benthic food flow to fish reflected in the SI data (Fig. 3, Table 3) was manifest despite high levels of total zooplankton biomass in inshore regions (Hart, 2012), concurrently with the 'benthic' resources available. Further, zooplankton biomass was not only high, but also comprised a strong component of large-bodied Daphnia (Hart, 2012), well-known to be selectively predated by zooplanktivorous fish (e.g. Jeppesen et al., 2003; Gliwicz, 2005; Lampert 2006; Gliwicz et al., 2010) - a keystone feature of the classical size-efficiency hypothesis (Brooks and Dodson, 1965; Hart and Bychek, 2011). These findings firmly substantiate our overall conclusion that the food-web leading to fish in Rietvlei is primarily routed through benthic rather than planktonic resources. The fate of planktonic primary production cannot be determined from the present analysis, but is logically expected to fuel a separate detritus-based food chain with some indirect links and subsidies to fish via zoobenthos.

Fish are increasingly recognised as 'integrators' of benthic and pelagic food-webs in (natural) lakes (Vander Zanden and Vadeboncoeur, 2002). This stems from the widespread utilisation of both planktonic and benthic resources ('trophic duality') of lacustrine fish, and results in $\delta^{13} \mathrm{C}$ signatures being weighted averages of the proportional contribution of food types in the mixed diet. The fish results for Rietvlei (Fig. 3) provide little indication of such dietary mixing; apart from Clarias, their $\delta^{13} \mathrm{C}$ signatures are not convincingly intermediate between planktonic and benthic primary producers (epiphytes excluded), but rather align with benthic macrophyte resources.

The absence of trophic duality in Rietvlei fish is logically explicable from obvious fundamental differences in ecosystem structure and functioning of lacustrine and riverine ecosystems (e.g. Wetzel, 2001) that generate consequential differences between natural lakes and reservoirs. Natural lakes are generally plankton-dominated ecosystems, in which specialist planktivorous fish have evolved to utilise this resource. In contrast, the general scarcity of plankton in flowing waters precludes the evolution of planktivorous riverine fish. Native reservoir fish comprise a subset of species derived from the riverine assemblage, and consequently lack planktivorous species able to exploit planktonic resources that proliferate in the resulting artificial lake. Hardly surprisingly, zooplankton does not feature in the diet of 'indigenous' reservoir fish, commonly leading to purposeful introductions of specialised non-native 
pelagic zooplanktivores to fill a vacant trophic niche. The Lake Tanganyika sardine Limnothrissa miodon in Lake Kariba (Marshall, 1991) is a notable African example; in Australian reservoirs, zooplanktivory is mostly attributable to alien fish (Matveev et al., 2002).

Pelagic fish are undoubtedly scarce in South African reservoirs. Offshore stocks of species that occur (more likely as migrants than residents) in open water (notably Clarias and Cyprinus) are certainly relatively low - implicitly accounting for the restriction of collecting activities and sampling efforts to near-shore/littoral regions (e.g. see NIWR, 1985; Koekemoer and Steyn, 2005; Harding and Koekemoer, 2011). In keeping with this, zooplankton-phytoplankton (Z/P) biomass ratios determined from offshore samples are relatively high (Hart, 2011), on account of limited zooplanktivory. And contrary to the general decline in $\mathrm{Z} / \mathrm{P}$ values with trophic status observed in natural lakes, attributed to rising fish predation and justifying fish removal (Jeppesen et al., 2003), they rise with trophic status in South African reservoirs (Hart, 2011). Thus, any need for fish removal in the 'pelagic' zone, which generally covers most of the surface area and invariably holds the greatest volume of water stored in reservoirs, is accordingly negated. In effect, biomanipulation is rendered redundant.

Biomanipulation proposals for South African reservoirs were advocated on grounds of reducing 'coarse' fish said to dominate in eutrophic and hypertrophic reservoirs. However, such dominance is not strictly limited to, or inevitable in eutrophic systems. Coarse fish accounted for 39.1 to $71.3 \%$ (average $=64.2 \%$ ) of total fish biomass in 2 eutrophic and 3 hypertrophic systems, and from 39.3 to $79.7 \%$ (average $=55.2 \%$ ) in 2 mesotrophic 'control' reservoirs surveyed by Harding and Koekemoer (2011). Apart from their negligible role in zooplanktivory, their stated undesirability on account of bioturbation will certainly be spatially limited by hypoxic conditions that develop in eutrophic waters, especially in summer.

The insignificance of zooplankton in the diet of Rietvlei fish accords with previous findings for Hartbeespoort Dam, a nearby hypertrophic system (NIWR, 1985). Although zooplankton was recorded in the diet of all four major fish species in that ecosystem, it occurred, respectively, in only $25 \%, 12 \%$, $6 \%$ and $4 \%$ of Clarias, Oreochromis mossambicus, Cyprinus and Chetia specimens examined ( $n=76,745,136$ and 95) (see Fig. 5.76 in NIWR, 1985). Even the highest value (25\% in Clarias) does not reflect dietary importance; a similar value (26.1\%) reported for this species elsewhere translated into a gravimetric contribution of $<0.10 \%$ (Kadye and Booth, 2012)). Conversely, the importance of benthic components (zoobenthos, aquatic insects, detritus and plant matter) in the diets of Clarias, Cyprinus and Chetia in Hartbeespoort Dam (NIWR, 1985) strongly implies that its food-web is also predominantly based on benthic rather than planktonic resources, notwithstanding an enormous biomass of planktonic Microcystis (NIWR, 1985).

\section{Opportunistic zooplanktivory}

Suggestions regarding opportunistic zooplanktivory by juvenile fish (Hart, 2006) cannot be tested using the present SI results mostly obtained from adult specimens (see Table 1). Nevertheless, regular comparative determinations of zooplankton abundance and composition at inshore and offshore sites (undertaken concurrently with this SI study) provided no indications of significant fish predation on zooplankton, either spatially or temporally (Hart, 2012). Volumetrically, total zooplankton biomass was invariably higher inshore than offshore, with broadly equivalent contributions of large-bodied Daphnia, and did not vary over time in any way suggestive of seasonal changes in fish predation linked to increases in juvenile fish stocks (Hart, 2012).

A previous study of seasonal differences in the diets of different size-classes of fish in Hartbeespoort Dam (NIWR, 1985) found that little zooplankton was consumed by juvenile Cyprinus, while juvenile Clarias consumed none. Only larger catfish (> $500 \mathrm{~g}$ ) have a buccal cavity large enough to 'gulp' and screen sufficient volumes of water to catch meaningful quantities of zooplankton (Bruton, 1979). Although no information was obtained for Chetia, zooplankton formed an important dietary component of juvenile Oreochromis, another cichlid, during summer (NIWR, 1985). These mixed observations on the existence and extent of zooplanktivory by juvenile fish identify a need for further investigation of this topic. For example, how does the well-known shelter-seeking behaviour exhibited by many juvenile fish to avoid daytime predators (e.g. LoweMcConnell, 1987; Wootton 1990; Gerking, 1994; Jobling, 1995) influence their potential role as visual zooplanktivores? Does zooplanktivory by fish larvae differ between mouth-brooding taxa and those lacking this parental protection? It is widely stated that fish almost invariably rely on planktonic resources at some (especially larval or juvenile) stage of their lives (e.g. Duncan, 1997; Wootton, 1990; Gerking, 1994; Jobling, 1995). Is this truly applicable among riverine taxa, particularly those eventually found in reservoirs?

\section{Isotope variability and its origins}

Some variability in ambient $\delta^{13} \mathrm{C}$ and $\delta^{15} \mathrm{~N}$ values in reservoir ecosystems understandably stems from variations in the type and quantity of land-derived solutes and particulates of potentially different ${ }^{13} \mathrm{C}$ and ${ }^{15} \mathrm{~N}$ content carried by their influent rivers. However, based on the SIA precept of unique $\delta^{13} \mathrm{C}$ signatures for given food items, for example $-28 \%$ for C3 and $-13 \%$ for C4 plants (Peterson and Fry, 1987; Karasov and Martínez del Rio, 2007), the range in absolute SI values and their temporal variability in Rietvlei were unexpectedly large (Fig. 2). Site-averaged $\delta^{13} \mathrm{C}$ values of primary aquatic food sources varied around twofold during this 30 -month study (from -27.8 to $-15.3 \%$ in phytoplankton, -26.9 to $-16.9 \%$ in macrophytes and -23.1 to $-10.5 \%$ in epiphytes). The corresponding ranges for $\delta^{15} \mathrm{~N}$ were 2.9 to $20.3 \%$, 12.0 to $21.1 \%$ and 13.3 to $17.8 \%$. These variations, largely of temporal origin (Fig. 2), strongly endorse Grey's (2006) cautions regarding the use of once-off samples to deduce trophic linkages in a 'complete' food-web comprising biotic components with widely different rates of isotopic assimilation.

Explaining this variability is not simple. Phytoplankton rely on various forms of dissolved inorganic carbon (DIC), principally $\mathrm{CO}_{2}, \mathrm{HCO}_{3}^{-}$and $\mathrm{CO}_{3}{ }^{2-}$, as a carbon source (Reynolds, 2006). The ${ }^{13} \mathrm{C}$ content of these moieties is determined by the respective contributions of atmospheric, geological and organic components of the carbon cycle to gaseous and eventually dissolved $\mathrm{CO}_{2}$ (Peterson and Fry, 1987). Changes in the source(s) and mix of these carbon components drive changes in the ${ }^{13} \mathrm{C}$ content of DIC, with subsequent photosynthetic carbon fractionation influencing the eventual $\delta^{13} \mathrm{C}$ values. Photosynthetic carbon fractionation differs between species, principally on account of different specific growth-rate-limiting resources 
(Riebesell et al., 2000), such that $\delta^{13} \mathrm{C}$ differences $>10 \%$ can exist between co-occurring phytoplankton taxa (Vuorio et al., 2006). Temporal changes in taxonomic composition can thus influence the $\delta^{13} \mathrm{C}$ value of pooled phytoplankton. Temperature-controlled changes in $\mathrm{CO}_{2}$ solubility which influence photosynthetic ${ }^{13} \mathrm{C}$ fractionation result in further temporal variability in phytoplankton $\delta^{13} \mathrm{C}$. Thermal stratification strongly influences eventual $\delta^{13} \mathrm{C}$ values as a result of its effects on interacting physical, chemical and biological processes (Zohary et al., 1994).

The complexity of such influences precludes a direct explanation for the changes in $\delta^{13} \mathrm{C}$ observed in Rietvlei. Other studies of freshwater phytoplankton have found both considerably greater ( 28\%o: Vuorio et al., 2006) and far smaller ( 3\%o: Grey and Jones, 2001; Caroni et al., 2012) temporal changes in $\delta^{13} \mathrm{C}$ than observed in Rietvlei (12.5\%).

Biotic nitrogen supplies also comprise a mixture of various inorganic and organic components differing in ${ }^{15} \mathrm{~N}$ content, eventually reflected in the $\delta^{15} \mathrm{~N}$ values of primary producers. Since selective bacterial uptake of ${ }^{14} \mathrm{~N}$ in sewage treatment plants is widely known to result in ${ }^{15} \mathrm{~N}$-enriched effluents (Heaton, 1986), some of the temporal variation in autotroph $\delta^{15} \mathrm{~N}$ values in Rietvlei (Fig. 2) plausibly arises from changing effluent releases from the Hartbeesfontein wastewater treatment works upstream on the Hennops River.

As for carbon, wide taxonomic differences in $\delta^{15} \mathrm{~N}$ are also evident, with a range of up to $11 \%$ reported in co-occurring taxa (Vuorio et al., 2006); some explanations regarding $\delta^{13} \mathrm{C}$ variation given above pertain for $\delta^{15} \mathrm{~N}$. The radical and inexplicable decline in phytoplankton $\delta^{15} \mathrm{~N}$ in the winter of 2010 (Fig. 2) is particularly noteworthy, given that no corresponding decline was evident either in other producers (macrophytes) or their putative consumers (zooplankton). Intriguingly, phytoplankton and zooplankton $\delta^{13} \mathrm{C}$ values were also lowest at this time (Fig. 2).

\section{Zooplankton food sources}

The close correspondence of $\delta^{13} \mathrm{C}$ values in zooplankton and phytoplankton is consistent with anticipated feeding links between them. However, given recent recognition that zooplankton in small lakes relies heavily on allochthonous (terrestrial) carbon sources (e.g., 30-40\% of their diet: Cole et al., 2011), it is also enigmatic. In reservoirs, direct imports of terrestrial POM by influent rivers are expected to provide a major, probably greater 'subsidy'. Do zooplankton and phytoplankton $\delta^{13} \mathrm{C}$ values in Rietvlei correspond because such allochthonous $\mathrm{POM}$ is not a significant food resource for its zooplankton? Or are the $\delta^{13} \mathrm{C}$ values of phytoplankton and POM simply comparable?

The correspondence in zooplankton and phytoplankton $\delta^{13} \mathrm{C}$ values is also notable given the dominance of large colonial or filamentous phytoplankton in hypertrophic systems like Rietvlei (Harding et al., 2012) and Hartbeespoort (NIWR, 1985). These producers are too large for direct consumption by zooplankton, particularly daphniids (e.g. Jarvis et al., 1987; Hanazato, 1991), resulting in a broken food link and large accumulations of detritus (NIWR, 1985). Although bacteria alone accounted for $<3 \%$ of the diet of cladoceran zooplankton in Hartbeespoort Dam (Hart and Jarvis, 1993), the ability of cladoceran and copepod zooplankton to consume and assimilate Microcystis detritus revealed in a recent SI study (Yu et al., 2013) suggests that alignment of phytoplankton and zooplankton $\delta^{13} \mathrm{C}$ values might partly reflect direct consumption of particulate detritus.

\section{CONCLUSION}

This study confirms the futility of 'top-down' biomanipulation as a counter-measure to manage eutrophic South African reservoirs. It endorses early warnings of an apparent panacea 'unsoundly based on many half-truths, much hand-waving and over extrapolation of data' (DeMelo et al., 1992). The probability that phytoplankton levels can be effectively controlled via top-down control of fish appears to be low (Benndorf, 1992), while positive control of food-webs remains elusive in large lakes and reservoirs (Matena et al., 1994) for many fundamental reasons (Gliwicz, 2005). Nutrient control remains the paramount focus for restoring eutrophic lakes (e.g. Moss et al., 2004), endorsing the maxim 'prevention is better than cure'. The determination and enforcement of system-specific total maximum daily (or annual) nutrient load limits (TMDLs) is essential for future conservation of potable water resources (Harding, 2008).

\section{ACKNOWLEDGEMENTS}

This work was undertaken with Water Research Commission funding as WRC Project K5/1918 'Food-web interactions in South African Reservoirs, tracked using stable isotopes'. Routine sampling was conscientiously undertaken by Mrs Lynda Muller (Envirowise), with indispensable logistical support from Rietvlei Nature Conservancy staff and the Tshwane Municipality's Rietvlei Laboratory. Stable isotope analyses were carried out meticulously by Prof John Lanham and Mr Ian Newton of the UCT Stable Isotope Laboratory. Mr JH Koekemoer (Koekemoer Aquatic Services) collected fish samples in October 2009. We acknowledge helpful comments and insights provided by two anonymous reviewers.

\section{REFERENCES}

ADAMS TS and STERNER RW (2000) The effect of dietary nitrogen content on trophic level ${ }^{15} \mathrm{~N}$ enrichment. Limnol. Oceanogr. 45 601-607.

AKHURST DJ, JONES GB, CLARK M and REICHELT-BRUSHETT A (2012) Effects of carp, gambusia and Australian bass on water quality in a subtropical freshwater reservoir. Lake Reservoir Manage. 28 $212-223$.

ANON (2004a) New hope for troubled waters: The Hartbeespoort Dam test case. The Water Wheel 3 (1) 16-19.

ANON (2004b) Hartbeespoort Dam: An action plan. The Water Wheel 3 (6) 6-10.

ASHTON PJ (1980) Rietvlei Dam. In: Limnology of Some Selected South African Impoundments. Collaborative Report by the Water Research Commission and the National Institute for Water Research, Council for Scientific and Industrial Research, Pretoria, South Africa. ISBN 0798817364.

ASHTON PJ (1981) Nitrogen fixation and the nitrogen budget of a eutrophic impoundment. Water Res. 15 823-833.

BENNDORF J (1992) The control of the indirect effects of biomanipulation. In: Sutcliffe DW and Jones JG (eds) Eutrophication: Research and Application to Water Supply. Freshwater Biological Association, Cumbria, UK. ISBN 0-900386-52-5.

BROOKS JL and DODSON SI (1965) Predation, body size, and composition of plankton. Science 150 28-35.

BRUTON MN (1979) The food and feeding behaviour of Clarias gariepinus (Pisces: Claridae) in Lake Sibaya, South Africa, with emphasis on its role as a predator of cichlids. Trans. Zool. Soc. Lond. 35 47-114.

CARONI R, FREE G, VISCONTI A and MANCA M (2012) Phytoplankton functional traits and seston stable isotopes signature: a functional-based approach in a deep, subalpine lake, Lake 
Maggiore (N. Italy). J. Limnol. 71 84-94.

CARPENTER SR (2005) Eutrophication of aquatic ecosystems: Bistability and soil phosphorus. Proc. Natl Acad. Sci. USA 102 10002-10005.

CODD GA, MORRISON LF and METCALF JS (2005) Cyanobacterial toxins: risk management for health protection. Toxicol. Appl. Pharmacol. 203 264-272.

COLE JJ, CARPENTER SR, KITCHELL J, PACE ML, SOLOMON T and WEIDEL B (2011) Strong evidence for terrestrial support of zooplankton in small lakes based on stable isotopes of carbon, nitrogen, and hydrogen. Proc. Natl Acad. Sci. USA 108 1975-1980.

DeMELO R, FRANCE R AND MCQUEEN DJ (1992) Biomanipulation: Hit or Myth? Limnol. Oceanogr. 37 192-207.

DeNIRO MJ and EPSTEIN S (1978) Influence of diet on the distribution of carbon isotopes in animals. Geochim. Cosmochim. Acta 42 495-506.

DeNIRO MJ and EPSTEIN S (1981) Influence of diet on the distribution of nitrogen isotopes in animals. Geochim. Cosmochim. Acta 45 341-351.

DUNCAN A (1997) Quantifying the fish-zooplankton interaction as an ecosystem response. A historical account of the 16th PEG meeting 1984. Archiv für Hydrobiol. 49 139-152.

DWA (DEPARTMENT OF WATER AFFAIRS, SOUTH AFRICA) (2009) Green Drop Report 2009 version 1. South African Wastewater Quality Management Performance. Department of Water Affairs, Pretoria, South Africa.URL: http://www.dwaf.gov. za/Documents/GreenDropReport2009 ver1 web.pdf.

DWA (DEPARTMENT OF WATER AFFAIRS, SOUTH AFRICA) (2013) Draft National Water Resources Strategy 2 (NWRS 2): Managing Water for an Equitable and Sustainable Future. Comprehensive. Department of Water Affairs, Pretoria. URL: http://www.dwa.gov.za/nwrs/ (Accessed 16 July 2013).

FRONEMAN PW (2002) Food web structure in three contrasting estuaries determined using stable isotope $\left(\partial^{13} \mathrm{C}\right)$ analysis. Afr. J. Aquat. Sci. 27 107-115

FEUCHTMAYR H and GREY J (2003) Effect of preparation and preservation procedures on carbon and nitrogen stable isotope determinations from zooplankton. Rapid Commun. Mass Spectrom. 17 2605-2610.

GANNES LZ, O'BRIEN DM and MARTÍNEZ DEL RIO C (1997) Stable isotopes in animal ecology: assumptions, caveats, and a call for more laboratory experiments. Limnol. Oceanogr. 78 1271-1276.

GERKING SD (1994) Feeding Ecology of Fish. Academic Press, San Diego. xxv +416 pp.

GLIWICZ ZM (2005) Food web interactions: why are they reluctant to be manipulated? Verh. Int. Ver. Limnol. 29 73-88.

GLIWICZ ZM, SZYMANSKA E and WRZOSEK D (2010) Body size distribution in Daphnia populations as an effect of prey selectivity by planktivorous fish. Hydrobiologia 643 5-19.

GREY J (2006) The use of stable isotope analyses in freshwater ecology: current awareness. Pol. J. Ecol. 54 563-584.

GREY J and JONES RI (2001) Seasonal changes in the importance of the source of organic matter to the diet of zooplankton in Loch Ness, as indicated by stable isotope analysis. Limnol. Oceanogr. 46 505-513.

GULATI RD, LAMMENS EHRR, MEIJER M-L and VAN DONK E (eds.) (1990) Biomanipulation, tool for water management. Hydrobiologia 200/201 1-628.

HANAZATO T (1991) Interrelations between Microcystis and Cladocera in the highly eutrophic Lake Kasumigaura, Japan. Int. Rev. ges. Hydrobiol. 76 21-36.

HANSSON L-A, ANNADOTTER H, BERGMAN E, HAMRIN SF, JEPPESEN E, KAIRESALO T, LUOKKANEN E, NILSSON P-A, SØNDERGAARD M and STRAND J (1998) Biomanipulation as an application of food-chain theory: constraints, synthesis, and recommendations for temperate lakes. Ecosystems 1 558-574.

HARDING WR (2008) The determination of annual phosphorus loading limits for South African Dams. WRC Report No 1687/1/08. Water Research Commission, Pretoria. ISBN 978-1-77005-866-6.

HARDING WR, THORNTON JA, STEYN G, PANUSKA J and MORRISON IR (2004) Hartbeespoort Dam Remediation Project (Phase 1): Action Plan (Volume 1) Final Report. Report prepared for the Department of Agriculture, Conservation, Environment and Tourism, North West Province Government, South Africa. Project 58/2003.

HARDING WR, DOWNING TG, VAN GINKEL CE and MOOLMAN PM (2009) An overview of cyanobacterial research and management in South Africa post-2000. Water SA 35 479-484.

HARDING WR, HART RC and MULLER LG (2012) Elucidation of foodweb interactions in South African Reservoirs using stable isotopes. WRC Report No. 1918/1/12. Water Research Commission, Pretoria.

HARDING WR and KOEKEMOER JH (2011) Characterization of the fishery assemblages in a suite of eutrophic and hypertrophic South African Dams. WRC Report No. 1643/1/10. Water Research Commission, Pretoria. ISBN 978-1-4312-0054-2.

HART RC (2006) Foodweb (bio-)manipulation of South African reservoirs - viable eutrophication management prospect or illusory pipe dream? A reflective commentary and position paper. Water $S A$ 32 567-576

HART RC (2011) Zooplankton biomass to chlorophyll ratios in relation to trophic status within and between ten South African reservoirs: Causal inferences, and implications for biomanipulation. Water SA 37 513-522.

HART RC (2012) Zooplankton abundance and composition in the hypertrophic Rietvlei Dam, South Africa, negate prospects for its remedial 'top-down' biomanipulation. Afr. J. Aquat. Sci. 37 311-321.

HART RC and BYCHEK EA (2011) Body size in freshwater planktonic crustaceans: an overview of extrinsic determinants and modifying influences of biotic interactions. Hydrobiologia 668 61-108.

HART RC and JARVIS AC (1993) In situ determinations of bacterial selectivity and filtration rates by five cladoceran zooplankters in a hypertrophic subtropical reservoir. J. Plankton Res. 15 295-315.

HEATON THE (1986) Isotopic studies of nitrogen pollution in the hydrosphere and atmosphere: a review. Chem. Geol. 59 87-102.

HUNT RJ, MATVEEV V, JONES GJ and WARBURTON K (2003) Structuring of the cyanobacterial community by pelagic fish in subtropical reservoirs: experimental evidence from Australia. Freshwater Biol. 48 1482-1495.

IGLESIAS C, MAZZEO N, MEERHOFF N, LACEROT G, CLEMENTE JM, SCASSO F, KRUK K, GOYENOLA G, GARCÍA-ALONSO J, AMSINCK SL, PAGGI JC, DE PAGGI SJ and JEPPESEN E (2011) High predation is of key importance for dominance of smallbodied zooplankton in warm shallow lakes: evidence from lakes, fish exclosures and surface sediments. Hydrobiologia 667 133-147.

INGRAM TI, MATTHEWS B, HARROD C, STEPHENS T, GREY J, MARKEL R and MAZUMDER A (2007) Lipid extraction has little effect on the $\delta^{15} \mathrm{~N}$ of aquatic consumers. Limnol. Oceanogr.: Methods 5 338-343.

JARVIS AC, HART RC and COMBRINK S (1987) Zooplankton feeding on size fractionated Microcystis colonies and Chlorella in a hypertrophic lake (Hartbeespoort Dam, South Africa): implications to resource utilization and zooplankton succession. J. Plankton Res. 9 1231-1249.

JEPPESEN E (2008). Personal communication, July 2008. Stable isotope analyses on lakes. (Internal document.) Dr E Jeppesen, Aarhus University, Denmark.

JEPPESEN E, LANDKILDEHAUS F, LAURIDSEN TL, JENSEN JP, BJERRING R, SØNDERGAARD M and AMSINCK SL (2002) Food web interactions in five Faroese lakes tracked by stable isotopes. Ann. Soc. Scient. Foroensis Suppl. 36 114-125.

JEPPESEN E, JENSEN JP, JENSEN C, FAAFENG B, HESSEN DO, SØNDERGAARD M, LAURIDSEN T, BRETTUM P and CHRISTOFFERSEN K (2003) The impact of nutrient state and lake depth on top-down control in the pelagic zone of lakes: a study of 466 lakes from the temperate zone to the arctic. Ecosystems 6 313-325.

JEPPESEN E. SØNDERGAARD M, MAZZEO N, MEERHOFF M, BRANCO CC, HUSZAR V and SCASSO F (2005) Lake restoration and biomanipulation in temperate lakes: relevance for subtropical and tropical lakes. In: Reddy MV (ed.) Restoration and Management of Tropical Eutrophic Lakes. Science Publishers, Enfield. 331-359. ISBN 1578083702. 
JEPPESEN E, MEERHOFF M, JACOBSEN BA, HANSEN RS, SØNDERGAARD M, JENSEN JP, LAURIDSEN TL, MAZZEO N and BRANCO CWC (2007) Restoration of shallow lakes by nutrient control and biomanipulation - the successful strategy varies with lake size and climate. Hydrobiologia 581 269-285.

JEPPESEN E, MEERHOFF M, HOLMGREN K, GONZALEZ BERGONZONI I, TEIXEIRA-DE MELLO F, DECLERCK SAJ, DE MEESTER L, SØNDERGAARD M, LAURIDSEN TL, BJERRING R, CONDE-PORCUNA JM, MAZZEO N, IGLESIAS C, REIZENSTEIN M, MALMQUIST HJ, LIU Z, BALAYIA D and LAZZARO X (2010) Impacts of climate warming on lake fish community structure and potential effects on ecosystem function. Hydrobiologia 646 73-90.

JOBLING M (1995) Environmental Biology of Fishes. Fish and Fisheries Series 16. Chapman and Hall, London, New York. xii + 455pp.

KARASOV WH and MARTÍNEZ DEL RIO C (2007) Isotopic ecology. Physiological Ecology. How Animals Process Energy, Nutrients, and Toxins. Princeton University Press, Princeton, USA. 433-478.

KADYE WT and BOOTH AJ (2012) Integrating stomach content and stable isotope analyses to elucidate the feeding habits of non-native sharptooth catfish Clarias gariepinus. Biol. Invasions 14 779-795.

KIBIRIGE I, PERISSINOTTO R and NOZAIS C (2002) Alternative food sources of zooplankton in a temporarily-open estuary: evidence from $\delta^{13} \mathrm{C}$ and $\delta^{15} \mathrm{~N}$. J. Plankton Res. 24 1089-1095.

KILJUNEN M, GREY J, SINISALO T, HARROD C, IMMONEN H and JONES RI (2006) A revised model for lipid-normalizing $\delta^{13} \mathrm{C}$ values from aquatic organisms, with implications for isotope mixing models. J. Appl. Ecol. 43 1213-1222.

KOEKEMOER JH AND STEYN GJ (2005) Fish community study of Hartbeespoort Dam. Final Report on Hartbeespoort Dam Remediation Project (Phase 1) to North West Province Department of Agriculture, Conservation, Environment and Tourism. $101 \mathrm{pp}$.

LAMPERT W (2006) Daphnia: model herbivore, predator and prey. Pol. J. Ecol. 54 607-620.

LOGAN JM, JARDINE TD, MILLER TJ, BUNN SE, CUNJAK RA and LUTCAVAGE ME (2008) Lipid corrections in carbon and nitrogen stable isotope analyses: comparison of chemical extraction and modelling methods. J. Anim. Ecol. 77 838-846.

LOWE-McCONNELL RH (1987) Ecological Studies in Tropical Fish Communities. Cambridge University Press, New York.

MARSHALL BE (1991) The Impact of the introduced sardine Limnothrissa miodon on the ecology of Lake Kariba. Biol. Conserv. 55 151-165.

MATENA J, VYHNÁLEK V and SIMEK K (1994) Food web management. In: Eiseltová M (ed.) Restoration of Lake Ecosystems - A Holistic Approach. International Water and Wetlands Bureau Publication 32. International Waterfowl and Wetlands Research Bureau, Gloucester, UK. ISBN 0950573159.

MATVEEV V, CLOSS G, LIESCHKE JA and SHIRLEY MJ (2002) Are pelagic fish important in the food webs of Australian reservoirs? Verh. Int. Ver. Limnol. 28 1-4.

MCCLELLAND JW and MONTOYA JP (2002) Trophic relationships and the nitrogen isotopic composition of amino acids in plankton. Ecology 83 2173-2180

MCCUTCHAN JH Jr, LEWIS WM Jr, KENDALL C and MCGRATH CC (2003) Variation in trophic shift for stable isotope ratios of carbon, nitrogen, and sulfur. Oikos 102 378-390.

MILL AC, PINNEGAR JK and POLUNIN NVC (2007) Explaining isotope trophic-step fractionation: why herbivorous fish are different. Funct. Ecol. 21 1137-1145.

MOSS B (1998) Shallow lakes biomanipulation and eutrophication. SCOPE Newsletter 29 1-45.

MOSS B, STEPHEN D, BALAYLA DM, BÉCARES E, COLLINGS SE, FERNÁNDEZ-ALÁEZ M, FERRIOL C, GARCIA P, GOMÁ J, GYLLSTRÖM M, HANSSON L-A, HIETALA J, KAIRESALO T, MIRACLE MR, ROMO, S, RUEDA J, RUSSELL V, STÅHLDELBANCO A, SVENSSON M, VAKKILAINEN K, VALENTIN M, VAN DE BUND WJ, VAN DONK E, VINCENTE E and VILLENA MJ (2004). Continental-scale patterns of nutrients and fish effects on shallow lakes: synthesis of pan-European mesocosm experiment. Freshwater Biol. 49 1633-1649.
NIWR (NATIONAL INSTITUTE FOR WATER RESEARCH) (1985) The Limnology of Hartbeespoort Dam. South African National Scientific Programmes Report No 110. Council for Scientific and Industrial Research, Pretoria. 1-269.

PETERSON BJ and FRY B (1987) Stable isotopes in ecosystem studies. Annu. Rev. Ecol. Syst. 18 293-320.

PINTO-COELHO R, PINEL-ALLOULM B, METHOT G and HAVENS KE (2005) Crustacean zooplankton in lakes and reservoirs of temperate and tropical regions: variation with trophic status. Can. J. Fish. Aquat. Sci. 62 348-361.

POST DM (2002) Using stable isotopes to estimate trophic position: models, methods, and assumptions. Ecology 83 703-718.

POST DM, LAYMAN CA, ARRINGTON DA, TAKIMOTO G, QUATTROCHI J and MONTAÑA CG (2007) Getting to the fat of the matter: models, methods and assumptions for dealing with lipids in stable isotope analyses. Oecologia 152 179-189.

POSTE AE, HECKY RE and GUILDFORD SJ (2011) Evaluating microcystin exposure risk through fish consumption. Environ. Sci. Technol. 45 5806-5811.

RASK M, OLIN M, HORPPILA J, LEHROVAARA A, VÄISÄNEN A, RUUHIJÄRVI and SAMMALKORPI I (2002) Zooplankton and fish communities in Finnish lakes of different trophic status: responses to eutrophication. Verh. Int. Ver. Limnol. 28 396-401.

REYNOLDS CS (2006) The Ecology of Phytoplankton. Cambridge University Press, Cambridge. 535 pp.

RICHOUX NB and FRONEMAN PW (2007) Assessment of spatial variation in carbon utilization by benthic and pelagic invertebrates in a temperate South African estuary using stable isotope signatures. Estuar. Coast. Shelf Sci. 71 545-558.

RIEBESELL U, BURKHARDT S, DAUELSBERG A and KROON B (2000) Carbon isotope fractionation by a marine diatom: dependence on the growth-rate-limiting resource. Mar. Ecol. Prog. Series $193295-303$.

ROBERTSON, AI, HEALEY MR and KING AJ (1997) Experimental manipulations of introduced carp (Cyprinus carpio) in billabongs. II. Impacts on benthic properties and processes. Mar. Freshwater Res. 48 435-443.

SCHLOSSER IJ (1987) The role of predation in age and size related habitat use by stream fishes. Ecology 68 651-659.

SHAPIRO J (1995) Lake restoration by biomanipulation - a personal view. Environ. Rev. 3 83-93.

SHAPIRO J, LAMARRA V and LYNCH M (1975) Biomanipulation: an ecosystem approach to lake restoration. In: Brezonik PL and Fox JL (eds.) Proceedings of a Symposium on Water Quality Management Through Biological Control. University of Florida, Gainesville. $85-96$.

SIERP MT, QIN JG and RECKNAGEL F (2009) Biomanipulation: a review of biological control measures in eutrophic waters and the potential for Murray cod Maccullochella peelii peelii to promote water quality in temperate Australia. Rev. Fish Biol. Fish. 19 143-165.

SKELTON PH (1993) A Complete Guide to the Freshwater Fishes of Southern Africa. Southern Book Publishers, Halfway House. 1-388.

SMITH VH and SCHINDLER DW (2009) Eutrophication science: where do we go from here? Trends in Ecol. Evol. 24 201-207.

SMYNTEK PM, TEECE MA, SCHULZ KL and THACKERAY SJ (2007) A standard protocol for stable isotope analysis of zooplankton in aquatic food web research using mass balance correction models. Limnol. Oceanogr. 52 2135-2146.

SØNDERGAARD M and JEPPESEN E (2007) Anthropogenic impacts on lake and stream ecosystems, and approaches to restoration. J. Appl. Ecol. 44 1089-1094.

SØREIDE JE, TAMELANDER T, HOP H, HOBSON KA and JOHANSEN I (2006) Sample preparation effects on stable $\mathrm{C}$ and $\mathrm{N}$ isotope values: a comparison of methods in Arctic marine food web studies. Mar. Ecol. Prog. Series 328 17-18.

TAYLOR JC, HARDING WR and ARCHIBALD CGM (2007) A Methods Manual for the Collection, Preparation and Analysis of Diatom Samples. Version 1.0. WRC Report No. TT 281/07. Water Research Commission, Pretoria.

THOMPSON DR, BURY SJ, HOBSON KA, WASSENAAR LI and SHANNON JP (2005) Stable isotopes in ecological studies. Oecologia 144 517-519.

http://dx.doi.org/10.4314/wsa.v39i5.5

Available on website http://www.wrc.org.za

ISSN 0378-4738 (Print) = Water SA Vol. 39 No. 5 October 2013

ISSN 1816-7950 (On-line) = Water SA Vol. 39 No. 5 October 2013 
VAN DER ZANDEN MJ and VADEBONCOEUR Y (2002) Fishes as integrators of benthic and pelagic food webs in lakes. Ecology 83 2152-2161.

VANDERKLIFT MA and PONSARD S (2003) Sources of variation in consumer-diet $\delta^{15} \mathrm{~N}$ enrichment: a meta-analysis. Oecologia 136 169-182.

VENTER P, KOEKEMOER J and STEYN G (2012) Hartbeespoort Dam Remediation: Food web restructuring. J. S. Afr. Inst. Civ. Eng. 20 31-34.

VUORIO K, MEILI M and SARVALA J (2006) Taxon-specific variation in the stable isotopic signatures $\left(\delta^{13} \mathrm{C}\right.$ and $\left.\delta^{15} \mathrm{~N}\right)$ of lake phytoplankton. Freshwater Biol. 51 807-822.
WERNER EE, GILLIAM JF, HALL DJ, and MITTELBACH GG (1983) An experimental test of the effects of predation risk on habitat use in fish. Ecology 64 1540-1548.

WETZEL RG (2001) Limnology: Lake and River Ecosystems ( $3^{\text {rd }}$ edn). Elsevier Science \& Technology, San Diego. 1006 pp.

WOOTTON RJ (1990) Ecology of teleost fishes. Fish and Fisheries Series 1. Chapman and Hall, London . xii + 404 pp.

YU J, LI Y, LIU X, LI K, CHEN F, GULATI R and LIU Z (2013) The fate of cyanobacterial detritus in the food web of Lake Taihu: a mesocosm study using ${ }^{13} \mathrm{C}$ and ${ }^{15} \mathrm{~N}$ labelling. Hydrobiologia $71039-46$.

ZOHARY T, EREZ J, GOPHEN M, BERMAN-FRANK I and STILLER M (1994) Seasonality of stable carbon isotopes within the pelagic food web of Lake Kinneret. Limnol. Oceanogr. 39 1030-1104. 